\title{
ANALISIS KOMPARATIF PENGARUH TRANSFORMATIONAL LEADERSHIP TERHADAP KINERJA SEKOLAH YANG DIMEDIASI STAKEHOLDER ENGAGEMENT PADA SMP NEGERI DAN SMP SWASTA DI JAWA TIMUR
}

\author{
Dewie Tri Wijayati \\ Universitas Negeri Surabaya \\ dewiewijayati@unesa.ac.id
}

\begin{abstract}
The purpose of this study is to analyze the application of transformational leadership patterns to support the realization of changes in the school system. The type of research used is explanatory with a quantitative approach. The population of this research is Public and Private Junior High Schools in Surabaya. The sample taken in this study was 40 schools. The data obtained were processed using SEM (Structural Equation Modeling) with the Smart PLS version 3.0 application program. The results provide empirical evidence to confirm that: transformational leadership has a positive effect on school performance; transformational leadership has a positive effect on stakeholder engagement; stakeholder engagement has a positive effect on school performance; stakeholder engagement mediates a positive transformational leadership relationship with school performance.
\end{abstract}

Keywords: East Java; Indonesia; school performance; stakeholder engagement; transformasional leadership.

\section{PENDAHULUAN}

Mengukur kinerja sekolah menjadi isu penting dalam Pengembangan Sekolah Seutuhnya (PSS)/ School Integrated Development (SID). Sejalan dengan semakin meningkatnya dinamika tuntutan dan permintaan masyarakat terhadap transparansi, akuntabilitas, fleksibiltas dan layanan yang lebih baik, maka pengukuran kinerja sekolah menjadi komponen kunci dalam perencanaan, pengembangan, implementasi dan pengelolaan/ manajemen sekolah (Othman \& Abdul Rauf 2009).

Mulyasa (2014: 5) menyatakan bahwa sukses tidaknya pendidikan dan pembelajaran di sekolah sangat dipengaruhi oleh kemampuan kepala sekolah dalam mengelola setiap komponen sekolah (who is behind the school). Kemampuan yang dimaksud dari pendapat di atas adalah pengetahuan dan pemahaman terhadap manajemen dan kepemimpinan, serta tugas yang dibebankan kepadanya. Menurut Yuki (2009: 8), kepemimpinan secara umum sebagai proses mempengaruhi orang lain untuk memahami dan setuju dengan apa yang perlu dilakukan dan bagaimana tugas itu dilakukan secara efektif serta proses untuk memfasilitasi upaya individu dan kolektif untuk mencapai tujuan bersama.

Kepala sekolah memiliki otonomi dalam memajukan dan mengembangkan sekolahnya dengan kewenangan yang dimilikinya, kepala sekolah harus bijaksana dan dapat memaksimalkan perannya dalam menindak lanjuti masalah-masalah yang sedang dihadapi sekolah serta terus menerus berupaya untuk meningkatkan kinerja, baik pada tingkat kelompok maupun organisasi. Fungsi dan substansi manajemen pendidikan yang dijalankan oleh kepala sekolah meliputi pengorganisasian sumber daya pendidikan, proses pendidikan, dan pembelajaran serta pengelolaan mutu output (Lambert, 2003).

Berdasarkan uraian di atas, kepemimpinan yang dianggap dapat mewujudkan sekolah berkualitas, berprestasi dan bermutu dalam arti memiliki kinerja yang baik sesuai dengan kondisi dan kebutuhan sekarang adalah kepemimpinan kepala sekolah dengan model transformasional. Danim (2009: 47) juga menjelaskan bahwa kepala sekolah sebagai pimpinan adalah subjek yang harus melakukan transformasi kepemimpinan melalui pemberian bimbingan, tuntunan atau anjuran kepada yang dipimpinnya agar tujuan sekolah tercapai. Penerapan pola kepemimpinan transformasional dapat menunjang terwujudnya perubahan sistem persekolahan.

Penelitian ini bertujuan menganalisis komparatif pengaruh transformational leadership terhadap kinerja sekolah yang dimediasi stakeholder engagement pada SMP Negeri dan SMP Swasta di Jawa Timur. 


\section{KAJIAN PUSTAKA DAN PENGEMBANGAN HIPOTESIS}

\section{School Performance}

Whittaker dalam Tangkilisan (2007: 171) mengemukakan pengukuran kinerja organisasi merupakan suatu alat manajemen yang digunakan untuk meningkatkan kualitas pengambilan keputusan dan akuntabilitas. Stout dalam (Tangkilisan, 2007: 174) mengemukakan pengukuran kinerja organisasi merupakan proses mencatat dan mengukur pencapaian pelaksanaan kegiatan dalam arah pencapaian misi melalui hasil-hasil yang ditampilkan berupa produk, jasa ataupun suatu proses.

Sekolah adalah organisasi yang mempunyai tugas utama memberikan layanan pendidikan bermutu kepada masyarakat (Heath \& McLaughlin, 1994). Terkait dengan layanan pendidikan tersebut, pemerintah telah menetapkan Standar Pendidikan Nasional (SPN) sebagai dasar rujukan untuk mengukur kinerja sekolah. Sebagaimana tertuang dalam PP Nomor 19 Tahun 2005, terdapat delapan Standar Pendidikan Nasional (SPN) yang dapat dijadikan rujukan untuk mengukur kinerja sekolah, sebagaimana tertuang dalam Pasal 2 Ayat (1), yaitu standar isi, standar proses, standar kompetensi lulusan, standar pendidik dan tenaga kependidikan, standar sarana dan prasarana, standar pengelolaan, standar pembiayaan, dan standar penilaian pendidikan. Delapan Standar Nasional Pendidikan tersebut dapat dijadikan dimensi untuk mengukur mutu kinerja sekolah.

(a) Dimensi kurikulum didefinisikan sebagai kelengkapan dokumen kurikulum yang ada di sekolah, meliputi dokumen kurikulum, dokumen perangkat kurikulum, dokumen pendukung perangkat kurikulum. (b) Dimensi proses pembelajaran didefinisikan sebagai pelaksanaan pembelajaran di sekolah untuk mencapai standar kompetensi lulusan, meliputi perencanaan pembelajaran, proses pembelajaran, penilaian hasil pembelajaran, dan pengawasan pelaksanaan pembelajaran. (c) Dimensi kompetensi lulusan, didefinisikan sebagai kualifikasi kemampuan lulusan berupa prestasi akademik dan prestasi non akademik. (d) Dimensi penilaian, didefinisikan sebagai proses pengumpulan dan pengolahan informasi untuk mengukur pencapaian hasil belajar peserta didik. (e) Dimensi pendidik dan tenaga kependidikan didefinisikan sebagai kualifikasi dan kualitas kinerja guru, tenaga administrasi, tenaga laboran, dan tenaga kebersihan. (f) Dimensi sarana dan prasarana didefinisikan sebagai kualitas dan kuantitas fasilitas pendidikan untuk menunjang fasilitas pembelajaran. Dimensi ini meliputi sarana fisik, media pembelajaran, alat peraga/praktek, dan perpustakaan. (g) Dimensi pengelolaan didefinisikan sebagai aktivitas: (1) merencanakan program sekolah; (2) implementasi rencana kerja sekolah; serta (3) pengawasan, untuk mencapai efisiensi dan efektivitas penyelenggaraan pendidikan di sekolah.

\section{Transformational Leadership}

Kepemimpinan transformasional adalah gaya kepemimpinan di mana pemimpin bertujuan untuk menginspirasi pengikut dengan mengajukan banding untuk kebutuhan tingkat tinggi mereka untuk aktualisasi diri (Van Den Bosch \& Volberda, 2012). Kepemimpinan transformasional dapat merangsang inovasi produk lebih efektif daripada kepemimpinan transaksional karena karyawan bekerja di bawah penghargaan dan pemberian hukuman (transactional leadership) cenderung mengejar tujuan jangka pendek sambil mengabaikan manfaat inovasi jangka panjang (Jansen et al., 2009). Kepemimpinan transformasional menurut Luthan (2002), mempunyai ciri-ciri sebagai berikut. (a) Kharisma: memberi visi dan peka pada misi, menanamkan kebanggaan, membangun kepercayaan dan rasa hormat. (b) Inspiration: komunikasi sangat baik, menggunakan simbol untuk fokus usaha, mengungkapkan tujuan dengan cara mudah mudah. (c) Intelelectual stimulation: mendorong intelejensi, rasionalitas, dan hati-hati menyelesaikan masalah. (d) Individual consideration: memberi perhatian personal, memperlakukan bawahan secara individual, melatih, mengarahkan, membimbing.

Navickaitè (2013) menjelaskan kepemimpinan transformasional kepala sekolah sambil menerapkan perubahan organisasi di sekolah yang membutuhkan kepemimpinan transformasional bagaimana harus menerima perubahan dan perkembangan. Fisher (2005) berkonsentrasi pada waktu perubahan kasih sayang dan sumber daya manusia secara efektif dan efisien untuk kesuksesan berubah untuk berguna. (Peus et al., 2009) membahas variabel yang telah diidentifikasi sebagai faktor keberhasilan 
Dewie Tri Wijayati. Analisis Komparatif Pengaruh Transformational Leadership terhadap Kinerja Sekolah yang Dimediasi Stakeholder Engagement pada SMP Negeri dan SMP Swasta di Jawa Timur

inisiatif perubahan organisasi. Dia menemukan bahwa yang paling efektif dalam memimpin perubahan organisasi ialah gaya kepemimpinan transformasional yang mencakup komunikasi, visi menyeluruh dan menantang tujuan, serta penyediaan pertimbangan dan dukungan individual. Perilaku kepemimpinan transformasional menurut Bass \& Avio (1990) yaitu sebagai berikut.

(1) Pengaruh idealisasi, adalah salah satu perilaku paling menonjol dari pemimpin transformasional yang diekspresikan dengan bertindak sebagai model peran yang meningkatkan kepercayaan dan integritas mereka terhadap karyawan atau bawahan. (2) Stimulasi intelektual, adalah salah satu perilaku paling menonjol dari seorang pemimpin transformasional, ditunjukkan dengan menantang status quo dan mendorong karyawan untuk kreativitas dan inovasi. (3) Pertimbangan individu sebagai perilaku kepemimpinan transformasional paling signifikan kedua yaitu pemimpin memperluas dukungannya dari level grup atau organisasi ke level individu, sehingga karyawan dapat mengkomunikasikan ide-ide baru mereka tanpa keengganan dan ketakutan dan pengakuan di tingkat individu dan hal tersebut dapat dipastikan untuk kinerja yang lebih baik. Seorang pemimpin dengan perilaku transformasional mencoba mengeksplorasi kebutuhan individu rekannya. (4) Motivasi inspirasional, adalah perilaku karismatik para pemimpin transformasional. Kepemimpinan transformasional adalah konsep orang yang menginspirasi staf untuk bekerja sesuai tujuan atau visi perusahaan mereka. Kepemimpinan transformasional akan dibuat, dikomunikasikan dan menjadi panutan bagi staf mereka (McShane \& Von Glinow, 2009).

\section{Stakeholder Engagement}

Menurut Henderson \& Sun (2016) menjelaskan bahwa kepemimpan transfomasinal ini merujuk keterlibatan stakeholder yang inklusif dan mendorong adanya pemimpin yang memiliki gaya transformasional dalam organisasi. Selain itu, riset empiris yang telah dilakukan Henderson \& Sun (2016) juga menjelaskan bahwa keterlibatan stakeholder menghasilkan konflik yang dapat berpengaruh positif pada kinerja organisasi publik.

\section{Hubungan antar Variabel}

Khalili (2016) menjelaskan bahwa pemimpin sebagai panutan bagi karyawan dan hal ini berdampak pada kinerja yang baik bagi karyawan. (Sethibe \& Steyn, 2015) menjelakan bahwa transformational leadership berpengaruh pada kinerja organisasi. Kepemimpinan transformasional memiliki efek positif pada inovasi produk dan kinerja perusahaan (Matzler et al., 2008). Bawahan juga lebih mudah menerima partisipasi pemangku kepentingan ketika para pemimpin mereka menunjukkan perilaku yang lebih berorientasi pada transformasi. Pemimpin transformasional berfungsi sebagai panutan bagi karyawan (Shamir et al., 1993).

\section{H1 : Diduga transformational leadership berpengaruh positif terhadap school performance.}

Pemimpin dengan gaya kepemimpinan transformasional menekankan peran stakeholder dalam pengambilan keputusan ketika berbicara tentang keyakinan atau terlibat dalam perilaku yang relevan yang menganjurkan partisipasi. Selain itu, pemimpin transformasional dapat mengintegrasikan nilai pemangku kepentingan partisipasi dalam menentukan tujuan dan panduan organisasi tindakan dan kebijakan selanjutnya, sehingga menginspirasi karyawan untuk menghargai dan mengadopsi nilai partisipasi pemangku kepentingan (Groves \& LaRocca, 2011). Sebagai organisasi publik dan kebijakan menangani masalah sosial yang kompleks, kemampuan pemimpin transformasional merangsang karyawan untuk berpikir secara luas tentang inklusi, kolaborasi, dan kerja sama dengan yang berbeda kelompok pemangku kepentingan adalah manfaat jangka panjang bagi organisasi.

\section{$\mathrm{H} 2$ : Diduga transformational leadership berpengaruh positif terhadap stakeholder engagement.}

Memahami faktor-faktor yang dapat mempengaruhi tingkat kinerja sekolah pada level rendah dalam konteks negara Brazil, khususnya peran keterlibatan pemangku kepentingan dalam kebijakan publik yang terletak pada pendanaan keuangan berperan sangat penting dalam mempercepat peningkatan kinerja sekolah (Rocha \& Funchal, 2018). Pemahaman seperti itu penting dari sudut pandang 
akademis dan juga bagi manajer dari bidang pendidikan mengingat pengaruh positif kualitas pendidikan terhadap kemajuan indikator sosial dan ekonomi suatu negara.

H3 : Diduga stakeholder engagement berpengaruh positif terhadap school performance.

Menurut Henderson \& Sun (2016) menjelaskan bahwa kepemimpan transfomasinal ini merujuk keterlibatan stakeholder yang inklusif dan didorong adanya pemimpin yang yang memiliki gaya transformasional dalam organisasi. Selain itu, riset empiris yang telah dilakukan Henderson \& Sun (2016) juga menjelaskan bahwa keterlibatan stakeholder menghasilkan konflik yang dapat berpengaruh positif pada kinerja organisasi publik.

H4: Diduga stakeholder leadership memediasi pengaruh transformational leadership terhadap school performance.

Gambar 1 menunjukkan model yang dihipotesiskan dari penelitian ini. Satu faktor individu bertindak sebagai variabel independen (transformasional leadership). Sedangkan, stakeholder engagement sebagai mediator dan school performance sebagai variabel dependen.

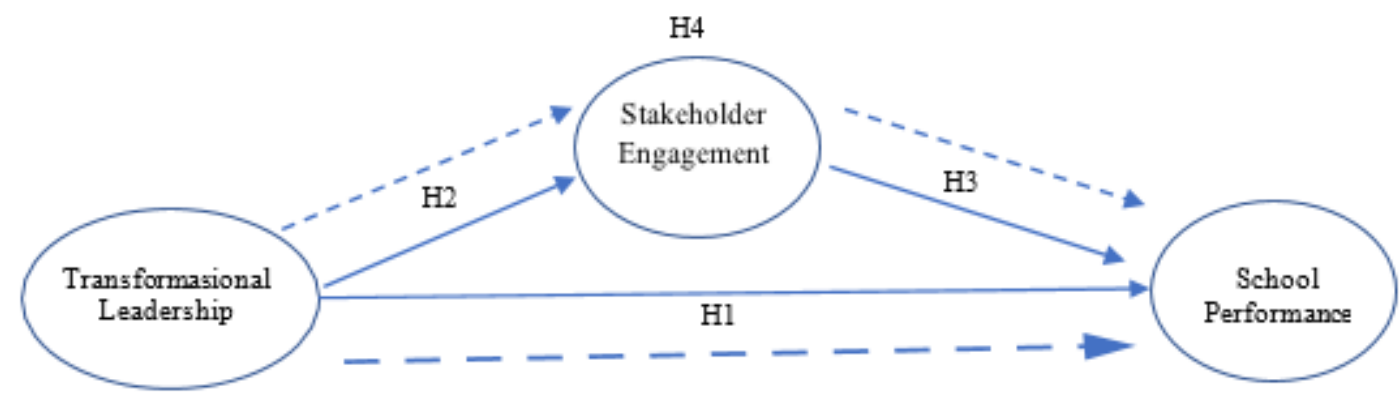

Gambar 1. MODEL PENELITIAN

\section{METODE PENELITIAN}

Jenis penelitian yang digunakan eksplanatori dengan pendekatan kuantitatif. Populasi penelitian ini adalah Sekolah Menengah Pertama Negeri dan Swasta di Surabaya. Pengambilan sampel dalam penelitian ini dilakukan dengan menggunakan beberapa pertimbangan tertentu. Untuk mempermudahkan pengambilan sampel, maka dalam penelitian ini sampel yang diambil adalah 40 sekolah. Transformational leadership diukur dengan 7 item menurut Henderson \& Sun (2016). Stakeholder engagement diukur oleh 6 item pernyataan yang dikembangkan oleh Henderson \& Sun (2016). Sedangkan school performance dibuat dari 14 item mengacu pada 8 dimensi yang merujuk kepada Standar Pendidikan Nasional (SPN), sebagaimana tertuang dalam PP Nomor 19 Tahun 2005 Pasal 2 Ayat 1. Semua item dinilai pada skala likert lima poin, dengan responden menunjukkan persetujuan atau ketidaksetujuan mereka dengan setiap pernyataan $(1=$ sangat tidak setuju dan $5=$ sangat setuju) (Sekaran \& Bougie, 2016: 215). Setelah melakukan pengumpulan data, tahap berikutnya adalah menganalisis data tersebut dengan menggunakan SEM (Structural Equation Modelling) dengan aplikasi program Smart PLS versi 3.0.

\section{HASIL DAN PEMBAHASAN}

\section{Hasil}

Tabel 1 menguraikan bahwa tidak ada masalah dengan validitas konvergen dan dianggap dapat diterima. Pemeriksaan ukuran semua item dari variabel laten ditemukan sebagai parameter yang valid. Nilai untuk setiap indikator dan hasil AVE melebihi nilai yang dipersyaratkan. Di sisi lain, nilai composite reliabilitiy dan Cronbach's Alpha masing-masing variabel melebih batas yang ditetapkan. 
Dewie Tri Wijayati. Analisis Komparatif Pengaruh Transformational Leadership terhadap Kinerja Sekolah yang Dimediasi Stakeholder Engagement pada SMP Negeri dan SMP Swasta di Jawa Timur

Tabel 2 menunjukkan hasil perhitungan $R$-Square antara variabel stakeholder engagement dan school performance memiliki nilai yang relatif berbeda. Hal ini dapat dilihat pada variabel stakeholder engagement yang memiliki nilai 0.606 atau $60.6 \%$ sedangkan variabel school performance adalah 0.721 atau $72.1 \%$. Variabel-variabel tersebut dapat dijelaskan dengan nilai R-Square dari transformational leadership dan faktor-faktor lain yang dijelaskan di luar variabel dalam penelitian ini.

Tabel 1.

SPECIFIED MEASUREMENT MODEL

\begin{tabular}{|c|c|c|c|c|c|}
\hline \multirow{2}{*}{ Latent Variable } & \multirow{2}{*}{$\begin{array}{c}\text { Indicators/ } \\
\text { Items }\end{array}$} & \multicolumn{2}{|c|}{ Convergent Validity } & \multirow{2}{*}{$\begin{array}{c}\text { Internal } \\
\text { Consistency } \\
\text { Composite } \\
\text { Reliability }\end{array}$} & \multirow{2}{*}{$\begin{array}{c}\text { Reliability } \\
\text { Cronbach } \\
\text { Alpha }\end{array}$} \\
\hline & & Outer Loadings & $A V E$ & & \\
\hline & & $>0.50$ & $>0.50$ & $>0.70$ & $>0.60$ \\
\hline Transformasional & TL1 & 0.764 & 0.545 & 0.893 & 0.862 \\
\hline Leadership & TL2 & 0.733 & & & \\
\hline \multirow[t]{5}{*}{ (X1) } & TL3 & 0.625 & & & \\
\hline & TL4 & 0.761 & & & \\
\hline & TL5 & 0.822 & & & \\
\hline & TL6 & 0.720 & & & \\
\hline & TL7 & 0.730 & & & \\
\hline Stakeholder & SE1 & 0.709 & 0.530 & 0.870 & 0.821 \\
\hline \multirow[t]{5}{*}{ Engagement (Z1) } & SE2 & 0.685 & & & \\
\hline & SE3 & 0.686 & & & \\
\hline & SE4 & 0.727 & & & \\
\hline & SE5 & 0.845 & & & \\
\hline & SE6 & 0.702 & & & \\
\hline School & SP1 & 0.756 & 0.570 & 0.949 & 0.942 \\
\hline Performance & SP2 & 0.775 & & & \\
\hline \multirow[t]{12}{*}{ (Y1) } & SP3 & 0.697 & & & \\
\hline & SP4 & 0.765 & & & \\
\hline & SP5 & 0.755 & & & \\
\hline & SP6 & 0.789 & & & \\
\hline & SP7 & 0.756 & & & \\
\hline & SP8 & 0.684 & & & \\
\hline & SP9 & 0.768 & & & \\
\hline & SP10 & 0.740 & & & \\
\hline & SP11 & 0.744 & & & \\
\hline & SP12 & 0.792 & & & \\
\hline & SP13 & 0.751 & & & \\
\hline & SP14 & 0.793 & & & \\
\hline
\end{tabular}

Untuk menguji tingkat signifikansi, t-statistik untuk semua jalur dibuat menggunakan fungsi bootstrap SmartPLS 3.0. Berdasarkan penilaian koefisien jalur, semua hubungan langsung ditemukan memiliki nilai-t $\geq 1.96$, yang signifikan pada tingkat signifikansi $<0.000$. Ringkasan dari hubungan tersebut ditunjukkan pada Tabel 3.

Tabel 2

R-SQUARE

\begin{tabular}{lc}
\hline \multicolumn{1}{c}{ VariabeL } & R-Square \\
\hline Stakeholder Engagement & 0.606 \\
School Performance & 0.721 \\
\hline
\end{tabular}

Analisis bootstrap menunjukkan bahwa pengaruh tidak langsung dari stakeholder engagement: $\beta=$ 0.502 signifikan dengan nilai $t$-statistics sebesar 4.060. Oleh karena itu, efek mediasi pengaruh tidak 
langsung (stakeholder engagement) signifikan secara statistik, dan dapat dijelaskan bahwa stakeholder engagement berperan sebagai partial mediation. Hasil analisis mediasi disajikan pada Tabel 3 .

Tabel 3.

HASIL PENGUJIAN HIPOTESIS

\begin{tabular}{lccccc}
\hline \multicolumn{1}{c}{ Hubungan } & & $\beta$ & T-Statistics & P-Value & Hasil \\
\hline $\begin{array}{l}\text { Transformational leadership } \\
\begin{array}{l}\text { School Performance } \\
\text { Transformational leadership }\end{array}\end{array}$ & $\rightarrow$ & 0.244 & 2.027 & 0.043 & $\mathrm{H} 1$ \\
$\begin{array}{l}\text { Stakeholder Engagement } \\
\text { Stakeholder Engagement } \rightarrow\end{array}$ & 0.778 & 7.344 & 0.000 & $\mathrm{H} 2$ \\
$\begin{array}{l}\text { School Performance } \\
\text { Transformational leadership } \rightarrow\end{array}$ & 0.645 & 5.236 & 0.000 & $\mathrm{t}$ \\
$\begin{array}{l}\text { Stakeholder Engagement } \\
\text { Performance }\end{array}$ & & & & terbukti \\
\hline
\end{tabular}

\section{Pengaruh Transformational Leadership terhadap School Performance}

Hasil penelitian menunjukan bahwa gaya kepemimpinan transformasional berpengaruh positif terhadap kinerja sekolah. Hasil penelitian ini sesuai dengan Khalili (2016) menjelaskan bahwa pemimpin sebagai panutan sebagai panutan bagi karyawan dan hal ini berdampak pada kinerja yang baik bagi karyawan. Sethibe \& Steyn, 2015 menjelakan bahwa transformational leadership berpengaruh pada kinerja organisasi.

Meningkatnya kinerja sekolah tidak lepas dari pengaruh individu, dimana kepemimpinan dengan pengaruh individu mampu memberikan visi dan misi, menanamkan kebanggan terhadap lembaga. Dalam prosesnya pimpinan sering memberikan arahan sesuai misi yang ditentukan oleh lembaga kepada setiap pengajar untuk lebih meningkatkan pelayanan baik didalam proses akademik serta non akademik. Penggunaan motivasi inspiratif oleh kepala sekolah bertujuan untuk memberikan pengarahan atau mengkomunikasikan sesuatu serta menginspirasi kepada setiap pengajar dengan menggunakan cara-cara yang mudah dipahami agar para murid lebih efektif dan efisien dalam proses belajar serta optimis terhadap tujuan/cita-cita yang ingin dicapainya.

Proses stimulasi intelektul merupakan gambaran seorang pemimpin yang mampu meningkatkan intelektual para guru, sehingga mereka mempunyai kesempatan untuk mengembangkan diri dan lebih cerdas dalam menyelesaikan masalah-masalah yang muncul pada sekolah. Salah satunya dengan cara membuat metode-metode baru berupa penugasan guru dan murid untuk mengikuti seminar-seminar dan studi banding antar sekolah, agar para guru dan murid memiliki pengalaman baru dan dapat dimanfaatkan bagi sekolah tempatnya mengabdi. Dengan beberapa perhatian yang diberikan oleh kepala sekolah hal itu mampu mendongkrak semangat mengajar dari para guru, dan berdampak positif pada kinerja sekolah.

\section{Pengaruh Transformational Leadership terhadap Stakeholder Engagement}

Hasil penelitian ini sesuai dengan Henderson \& Sun (2016) yang menjelaskan bahwa kepemimpan transfomasinal ini merujuk pada keterlibatan stakeholder yang inklusif yang disebabkan adanya dorongan pemimpin dengan gaya transformasional dalam organisasi. Dalam kaitannya dengan sekolah, para guru juga lebih mudah menerima partisipasi pemangku kepentingan ketika kepala sekolah mereka menunjukkan perilaku yang lebih berorientasi transformasi. Pemimpin transformasional berfungsi sebagai panutan bagi para pemangku kepentingan dan para guru di sekolah. Kepala sekolah dapat menekankan peran stakeholder engagement dalam pengambilan keputusan ketika berbicara tentang keyakinan atau terlibat dalam perilaku yang relevan yang menganjurkan partisipasi para guru di sekolah. 
Dewie Tri Wijayati. Analisis Komparatif Pengaruh Transformational Leadership terhadap Kinerja Sekolah yang Dimediasi Stakeholder Engagement pada SMP Negeri dan SMP Swasta di Jawa Timur

Selain itu, kepala sekolah dapat mengintegrasikan nilai partisipasi pemangku kepentingan dalam menentukan tujuan dan panduan sekolah, tindakan dan kebijakan selanjutnya, sehingga menginspirasi para guru untuk menghargai dan mengadopsi nilai partisipasi pemangku kepentingan di sekolah. Sebagai lembaga pendidikan yang berkewajiban untuk mencerdaskan kehidupan bangsa, kemampuan pemimpin transformasional untuk merangsang kemampuan stakeholder engagement untuk berpikir secara luas tentang inklusi, kolaborasi, dan kerja sama dengan yang berbeda kelompok pemangku kepentingan adalah manfaat jangka panjang bagi organisasi. Dengan hal tersebut terbukti bahwa kepala sekolah yang menerapkan gaya kepemimpinan transformasional dapat berpengaruh positif terhadap keterlibatan para pemangku kepentingan di sekolah.

\section{Pengaruh Stakeholder Engagement terhadap School Performance}

Hasil penelitian ini sesuai dengan Henderson \& Sun (2016) menjelaskan bahwa keterlibatan stakeholder menghasilkan konflik yang dapat berpengaruh positif pada kinerja organisasi publik. Keterlibatan pemangku kepentingan memiliki efek positif pada kreativitas dan inovasi guru sehingga berdampak pada kinerja sekolah. Selain itu dapat melalui agenda rutin atau pertemuan yang dilakukan oleh pemangku kepentingan dengan para wali siswa guna membahas pencapaian dan kesuksesan para siswa. Keterlibatan pemangku kepentingan juga dapat berupa tanggapan dari pihak sekolah yang kaitannya dengan pertanyaan-pertanyaan baik prestasi belajar atau masalah yang dihadapi oleh para siswa yang diajukan oleh para wali siswa, dengan rasa puas akan tanggapan yang diberikan hal tersebut membuat pandangan atau stigma baik dari para orang tua terhadap kinerja sekolah.

\section{Pengaruh Transformational leadership terhadap School Performance melalui Stakeholder Engagement}

Penelitian ini membuktikan peran mediasi (tidak langsung) dari stakeholder engagement pada pengaruh langsung transformational leadership terhadap school performance. Merujuk pada penelitian yang dilakukan oleh Henderson \& Sun (2016) menjelaskan bahwa kepemimpan transfomasinal ini merujuk keterlibatan stakeholder yang inklusif dan mendorong adanya pemimpin yang yang memiliki gaya transformasional dalam organisasi. Selain itu, riset empiris yang telah dilakukan Henderson \& Sun (2016) juga menjelaskan bahwa keterlibatan stakeholder menghasilkan konflik yang dapat berpengaruh positif pada kinerja organisasi publik.

Secara hasil di lapangan membuktikan bahwa kepala sekolah yang berkharisma, inspiratif, memiliki tingkat intelegensi dan rasionalitas yang baik serta memilki rasa mengayomi, mengarahkan dan membimbing bawahan dengan baik hal tersebut dapat merangsang secara sukarela para pemangku kepentingan untuk menyadari satu visi dan misi yang sama dan nantinya timbul rasa memiliki dan semangat yang tinggi guna berkolaboarasi dan saling mendukung untuk mengintegritaskan para guru lainnya. Dari keterlibatan sukarela para pemangku kepentingan tersebut, tentunya akan sangat membantu kepala sekolah dalam mengimplementasikan visi dan misi yang sudah dicita-citakan guna kemajuan lembaga/sekolah. Ini memberikan informasi bahwa semakin baik gaya kepemimpinan transformasional dari setiap kepala sekolah hal tersebut akan merangsang perilaku sukarela dari para pemangku kepentingan untuk membatu meningkatkan kinerja sekolah/lembaga.

\section{KESIMPULAN}

Sebagai kesimpulan, penelitian ini telah memberikan pemahaman penting tentang peran stakeholder engagement sebagai mediator transformational leadership sehingga dapat berpengaruh positif terhadap school performance. Dengan demikian, penelitian ini telah memberikan bukti empiris untuk mengkonfirmasi bahwa transformational leadership berpengaruh positif terhadap school performance, transformational leadership berpengaruh positif terhadap stakeholder engagement, stakeholder engagement berpengaruh positif terhadap school performance, dan stakeholder engagement memediasi hubungan positif transformational leadership terhadap school performance. Penelitian ini hanya dilakukan pada sekolah menengah di Jawa Timur. Penelitian selanjutnya dapat memperluas ke wilayah lain dan tingkat sekolah yang berbeda untuk generalisasi. Penelitian selanjutnya juga dapat melibatkan variabel organizational citizenship behavior. 


\section{DAFTAR PUSTAKA}

Bass, B. M., \& Avolio, B. J. (1990). Transformational leadership development: Manual for the multifactor leadership questionnaire. Palo Alto, CA: Consulting Psychologists Press.

ChanLin, L., Hong, J., Horng, J., Chang, S., \& Chu, H. (2006). Factors influencing technology integration in teaching-A Taiwanese perspective. Innovations in Education and Teaching International, 43(1), 57-68.

Chin, W. W. (1998). The Partial Least Squares Approach for Structural Equation Modeling. In Modern methods for business research (G A Marcou, pp. 295-336). London: Lawrence Erlbaum Associates.

Daskalakis, S., \& Mantas, J. (2008). Evaluating the impact of a service-oriented framework for healthcare interoperability. In Proceedings of MIE2008 (Studies in Health Technology and Informatics) (pp. 285-290). Amsterdam, Netherlands: IOS Press.

Esendemir, N.-, \& Zehir, C. (2017). Innovation and Performance: The Mediating Effect of Organizational Learning and Technological Capability. International Journal of Research in Business and Social Science (2147-4478), 6(4), 48. http://doi.org/10.20525/ijrbs.v6i4.747

Garson, G. D. (2016). Partial Least Squares: Regression \& Structural Equation Models (2016th ed.). Asheboro, NC 27205 USA: Statistical Publishing Associates.

Ghozali, I., \& Latan, H. (2015). PARTIAL LEAST SQUARES Concepts, Techniques and Applications Using the Smart 3.0 Program (2nd ed.). Semarang: Badan Penerbit Universitas Diponegoro.

Heath, S. B., \& McLaughlin, M. W. (1994). The best of both worlds: Connecting schools and community youth organizations for all-day, all-year learning. Educational Administration Quarterly, 30(3), 278-300.

Henderson, A. C., \& Sun, R. (2016). Transformational leadership and organizational processes: Influencing public performance. Public Administration Review, 77(4), 554-565. http://doi.org/10.1111/puar.12654

Henseler, J., Ringle, C. M., \& Sarstedt, M. (2012). Using Partial Least Squares Path Modeling in International Advertising Research: Basic Concepts and Recent Issues. In Handbook of Partial Least Squares: Concepts, Methods and Applications in Marketing and Related Fields (Okzaki, S, pp. 252-276). Berlin: Springer.

Höck, M., \& Ringle, C. M. (2006). Strategic Networks in The Software Industry: An Empirical Analysis of The Value Continuum. In IFSAM World Congress (VIII). Berlin. Retrieved from http://www.ibl-unihh.de/IFSAM06.pdf.

Hsiao, H. C., Chang, J. C., \& Tu, Y. L. (2010). Support for innovation, organizational learning, and organizational innova- tion in the vocational high schools: A Taiwanese perspective. International Journal ofTechnology and Engineering Education.

Khalili, A. (2016). Linking transformational leadership, creativity, innovation, and innovationsupportive climate. Management Decision, 54(9), 2277-2293. http://doi.org/10.1108/MD-032016-0196.

Indonesia, P. R. (2005). Peraturan Pemerintah Republik Indonesia nomor 19 tahun 2005 tentang 
Dewie Tri Wijayati. Analisis Komparatif Pengaruh Transformational Leadership terhadap Kinerja Sekolah yang Dimediasi Stakeholder Engagement pada SMP Negeri dan SMP Swasta di Jawa Timur standar nasional pendidikan. Departemen Pendidikan Nasional Republik Indonesia.

Lambert, L. (2003). Leadership capacity for lasting school improvement. Alexandria, USA: ASCD.

Rocha, A. B., \& Funchal, B. (2018). Do more resources mean better results? The relationship between direct school costs and performance in high school. Journal of Public Administration, 53(2), 291-309.

Samsu, \& Rusmini. (2016). The Influence of Principals' Leadership Styleson School Innovation in Jambi (Case Study in Several Senior High Schools in Jambi. At-Ta'lim Journa; , 23(1), 52-64.

Sattayaraksa, T., \& Boon-itt, S. (2018). The roles of CEO transformational leadership and organizational factors on product innovation performance. European Journal of Innovation Management, 21(2), 227-249. http://doi.org/10.1108/EJIM-06-2017-0077

Sethibe, T., \& Steyn, R. (2015). The Relationship Between Leadership Styles, Innovation And O Rganisational P Erformance : SAJEMS, 18(3), 325-337.

SPN (2005). Delapan Standar Pendidikan Nasional. Peraturan Pemerintah Nomor 19 Tahun 2005 Pasal 2 Ayat 1. Republik Indonesia: Jakarta.

Luthan, Fred, 2002, Organizational Behaviour, McGraww Hill, New York.

McRoy, I., \& Gibbs, K. S. (2009). Leading change in higher education. Educational Management and Administration, 37(5), 687-704.

McShane, S. L., \& Von Glinow, M. A. (2009). Organizational Behavior: Essemtols: New York: McGraw- Hill Companies, Inc.

Matzler, K., Schwarz, E., Deutinger, N. \& Harms, R. (2008), "The relationship between transformational leadership, product innovation and performances in SMEs", Journal of Small Business and Entrepreneurship, 21(2), 139-152.

Navickaitè, J. (2013). The expression of principal's transformational leadership during the organizational change process: A case study of Lithuanian general education school. Problems of Education in the 21st Century, 51, 70-82.

Peus C., Wesche J. S., Streicher B., Braun S., \& Frey D. (2012) Authentic Leadership: An Empirical Test of Its Antecedents, Consequences, and Mediating Mechanisms J Bus Ethics 107:331 348.

Sari, Fara M. \& Ibrahim, Mariyati. (2014). Penerapan Manajemen Perubahan Dan Inovasi. Jurnal Administrasi Pembangunan. 2(2). https://ejournal.unri.ac.id/index.php/JAP/article/view/2246

Xu, Qingrui. (2006), “Total Innovation Management: A Novel Paradigm of Innovation Management in the $21^{\text {st }}$ Century". Journal Technology Transfer. 32, 9-2 